\title{
Global Perspective of Legionella Infection in Community-Acquired Pneumonia: A Systematic Review and Meta-Analysis of Observational Studies
}

\author{
Frances F. Graham ${ }^{1, *}$, Norah Finn ${ }^{2}$, Paul White ${ }^{3}$, Simon Hales ${ }^{1}$ and Michael G. Baker ${ }^{1}(\mathbb{D})$ \\ 1 Department of Health, University of Otago, Wellington 6242, New Zealand; simon.hales@otago.ac.nz (S.H.); \\ Michael.Baker@otago.ac.nz (M.G.B.) \\ 2 Victorian Cancer Registry, Victorian Cancer Council, Melbourne, VIC 3004, Australia; \\ norah.finn@cancervic.org.au \\ 3 World Health Organization, Bangkok 11000, Thailand; paulwhiteships@hotmail.com \\ * Correspondence: grafr148@student.otago.ac.nz
}

check for

updates

Citation: Graham, F.F.; Finn, N.;

White, P.; Hales, S.; Baker, M.G. Global Perspective of Legionella Infection in Community-Acquired Pneumonia: A Systematic Review and Meta-Analysis of Observational Studies. Int. J. Environ. Res. Public Health 2022, 19, 1907. https:// doi.org/10.3390/ijerph19031907

Academic Editor: Beatrice Casini

Received: 3 October 2021

Accepted: 20 January 2022

Published: 8 February 2022

Publisher's Note: MDPI stays neutral with regard to jurisdictional claims in published maps and institutional affiliations.

Copyright: (c) 2022 by the authors. Licensee MDPI, Basel, Switzerland. This article is an open access article distributed under the terms and conditions of the Creative Commons Attribution (CC BY) license (https:/ / creativecommons.org/licenses/by/ $4.0 /)$.

\begin{abstract}
Legionnaires' disease (LD) (Legionella) is a common cause of community-acquired pneumonia (CAP) in those requiring hospitalization. Geographical variation in the importance of Legionella species as an aetiologic agent of CAP is poorly understood. We performed a systematic review and meta-analysis of population-based observational studies that reported the proportion of Legionella infection in patients with CAP (1 January 1990 to 31 May 2020). Using five electronic databases, articles were identified, appraised and reported in accordance with the Preferred Reporting Items for Systematic Reviews and Meta-Analysis (PRISMA) guidelines. The quality of the included studies was assessed using the Newcastle-Ottawa Scale. Univariate and multivariate meta-regression analyses were conducted using study design, WHO region, study quality and healthcare setting as the explanatory variables. We reviewed 2778 studies, of which 219 were included in the meta-analysis. The mean incidence of CAP was 46.7/100,000 population (95\% CI: 46.6-46.8). The mean proportion of Legionella as the causative agent for CAP was $4.6 \%$ (95\% CI: 4.4 to 4.7$)$. Consequently, the mean Legionella incidence rate was 2.8/100,000 population (95\% CI: 2.7-2.9). There was significant heterogeneity across all studies $I^{2}=99.27 \%(p<0.0001)$. After outliers were removed, there was a decrease in the heterogeneity $\left(I^{2}=43.53 \%\right)$. Legionella contribution to CAP has a global distribution. Although the rates appear highest in high income countries in temperate regions, there are insufficient studies from low- and middle-income countries to draw conclusions about the rates in these regions. Nevertheless, this study provides an estimate of the mean incidence of Legionella infection in CAP, which could be used to estimate the regional and global burden of LD to support efforts to reduce the impact of this infection as well as to fill important knowledge gaps.
\end{abstract}

Keywords: Legionella; community-acquired pneumonia; Legionnaires' disease; systematic review; meta-analysis

\section{Introduction}

Community-acquired pneumonia (CAP) is an acute infection of the pulmonary parenchyma that develops in persons outside of a hospital or health care facilities, such as nursing homes, hemodialysis centers and outpatient clinics. CAP is a leading cause of morbidity and mortality both in high- and low-income countries [1] making it of great epidemiological significance globally with noted seasonal [2] and regional [3] variations. Over 100 microorganisms have been identified as causative agents in CAP [4]. Historically, influenza and rhinovirus were the most commonly detected viral pathogens [5]. More recently, coupled with the increasing availability of molecular diagnostics, such as the polymerase chain reaction (PCR), the identification of bacterial pathogens in the etiology of CAP has increased [6]. Globally, Streptococcus pneumoniae is the most commonly recognized bacterial pathogen in CAP $[7,8]$. 
Recent studies identified Legionella species (spp.) as being among the four most frequent microbial causes of hospitalizations due to CAP $[9,10]$, accounting for $2 \%$ to $15 \%$ of patients as the cause of severe CAP requiring hospitalization [11,12]. Few studies have reported the incidence of Legionella as a cause of CAP outside the hospital setting. One study found Legionella to be equally common in outpatients and inpatients [13]. Furthermore, in an era of changing climate conditions globally, seasonal variations of microbial etiology are important for the future CAP, since S. pneumoniae and Legionella are clearly subject to seasonal variations where correlations with humidity and rainfall have been reported [14,15]. Despite several narrative reviews of the epidemiology of legionellosis (or Legionnaires' disease (LD)), a severe infection caused by Legionella spp.) [16-23], the global epidemiology of legionellosis is not well characterized. Published systematic reviews that have synthesized results of CAP etiology studies focusing on bacterial pathogens, including Legionella spp., are sparse and only performed among adults and limited to a specific WHO region [24]. Other systematic reviews focused on the prevalence of bacterial pathogens, including Legionella of patients with CAP, particularly in the outpatient primary care setting but excluded studies set in low- or middle-income countries (based on the Organisation for Economic Cooperation and Development (OECD) criteria) [25]. In the present analysis, we take the novel approach of looking at the global epidemiology of CAP as a way of then understanding and quantifying the contribution of legionellosis to that burden. In doing so, this review also seeks to augment a previous global systematic review and meta-analysis of seroprevalence studies of Legionella infection [26].The aim of this systematic review and meta-analysis is firstly to assess the contribution of Legionella infection in CAP, that is, those studies that measure the proportion of cases that are attributed to microbiologically confirmed Legionella infection. As Legionella cannot be distinguished clinically or radiographically from other types of pneumonia, any diagnosis of Legionella relies on the use of special laboratory tests [4,7], resulting in Legionella spp. being underdiagnosed in the etiology of CAP. Consequently, a second aim is to describe the many factors that might influence the sensitivity of Legionella diagnoses among CAP studies [27]. It is important to understand the causes of CAP to support the development of suitable prevention programs as well as selecting optimal antibiotic treatments [27].

\section{Materials and Methods}

\subsection{Search Strategy and Eligibility Criteria}

Our systematic review and meta-analysis followed the quality standards for reporting meta-analyses of observational studies in epidemiology [28] and PRISMA (Preferred Reporting Items for Systematic Reviews and Meta-Analyses) guidelines [29] (Figure S1). The study protocol is also registered with PROSPERO (CRD 42021259323). We examined articles published before 31 May 2020 in Medline (Ovid), Embase, Scopus, LILACS and the Cochrane Library using a modified version of the PRISMA search strategy. The following sources of gray literature were also searched until 31 May 2020: Te Puna, Kiwi Research Information Service, Proquest Dissertations and Theses, Index to Theses, OCLC FirstSearch: WorldCat, EThOS (Electronic Theses Online Service), OAIster, DART-Europe E-Theses Portal, Theses Canada, Trove, as well as GreyLit.org and OpenGrey.eu. PubMed (publisher: U.S.A. National Library of Medicine) was searched in addition to the MEDLINE database because the former also covers publications that are electronically published ahead of print. Figure $\mathrm{S} 2$ shows the search strategy.

We estimated the annual incidence for Legionella spp. infections in CAP in both outpatient and hospitalized patients using the search strategy in Figure 1. We included observational studies and reported data for the calculation of the incidence of Legionella infection in CAP in at-risk individuals for all age categories. The search consisted of four components: 1. 'pneumonia' or 'respiratory tract infection' in the title; 2. geographical terms anywhere in the citation using names of all countries; 3 . patient recruitment from 1 January 1990 and 4. observational studies that included patients with a diagnosis of CAP 
based on confirmation culture, polymerase chain reaction (PCR), serology or urine antigen testing (UAT) and reported the proportion of Legionella infection.

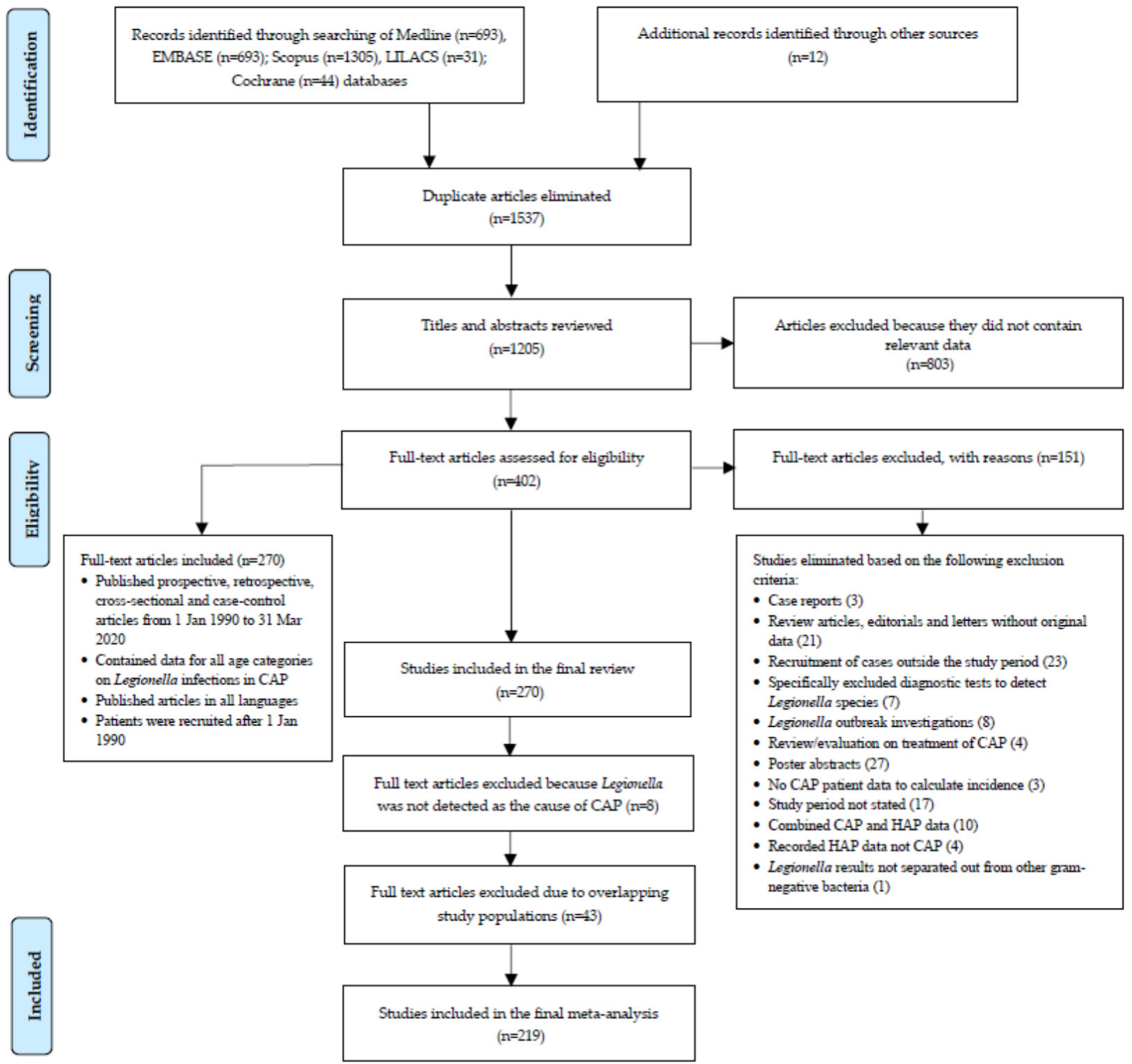

Figure 1. Flowchart of systematic literature review and study selection for meta-analysis.

All languages were eligible for inclusion and no publication restrictions were applied. All non-English articles were screened using Google Translate [30] or by a native speaker. The title and abstract of all the retrieved citations were reviewed, including studies with data on subgroups, such as the elderly or children, and the full text was retrieved if the abstract suggested the article contained data on Legionella in CAP etiology. The studies of CAP carried out on specific immunocompromised populations, such as patients with chronic obstructive pulmonary disease (COPD), HIV infection or diabetes mellitus, were reviewed. The reference lists of all the retrieved papers were manually searched for additional relevant studies. Where appropriate, some authors were contacted for further information, such as the study period. In circumstances where the same data were reported in more than one paper, the earliest published paper was selected. Legionellosis data were extracted and analyzed based on the number of cases, not the number of samples.

The exclusion criteria were as follows. (a) Studies addressing other aspects of CAP, such as hospital-acquired pneumonia (HAP), that is, patients with pneumonia occurring 
$48 \mathrm{~h}$ or more after hospital admission. Hospitalized patients with a diagnosis of ventilatorassociated pneumonia were also excluded. However, in circumstances where studies reported results containing both CAP and HAP data [31-35] only Legionellosis data specific to CAP was included in the meta-analysis. (b) Poster abstracts, brief communications, case reports, cases series, reviews/evaluations, editorials, correspondence without original data and laboratory-based studies of CAP (c) studies, which recruited CAP patients pre 1 January 1990. (d) Study period not stated. (e) The etiological role of Legionella was not included in the study design [36]. The complete search strategy is detailed in the Supplementary Appendix. Available gray literature, which predominantly comprised of national and jurisdictional reports describing the routine treatment and management of CAP, was not considered as useful for our review.

\subsection{CAP Definition and Study Population}

Studies on the microbial etiology of CAP show that the portion of causative pathogens varies geographically and by the study populations used, concurrent epidemics, microbiological techniques and definitions of the etiological diagnosis of CAP [37]. For the purposes of this review, we did not specify a CAP definition (including severe CAP) largely because it included such a heterogeneous patient group [38]. Rather, we accepted the authors' definition on the assumption that they gathered CAP data and used diagnostic tests to accurately classify CAP patients as having Legionella. Most studies, as a minimum, defined CAP as a chest radiograph showing new infiltrates or consolidation that could not be attributed to some other etiology, in the presence of acute onset fever, cough or sputum production.

Population estimates used to calculate annual incidence were derived from either published, national census data or mid-year estimates. The population figures were adjusted to reflect the age demographic inclusion criteria of each study.

\subsection{Data Extraction and Quality Assessment of Studies}

Data were extracted from each included study by one reviewer (FG) onto a standardized form that included data related to study characteristics (first author, year of publication, study design, WHO region, location, characteristics of study participants (number, patient recruitment period, mean or median age and male gender)) and the outcome of measures of interest, including the effect size of the data incidence of Legionella on CAP and case fatality risk (CFR). The healthcare setting was divided into five distinct settings: (1) inpatients not admitted to ICU; (2) ICU admitted patients; (3) outpatients with no-comorbidities; (4) outpatients with cardiopulmonary disease or other modifying factors; and (5) both inpatients (including ICU) and outpatients (Supplementary Table S1). We also reviewed studies to ascertain whether there was a correlation between meteorological conditions and sporadic cases of LD.

In order to assess the methodological quality of the observational studies, we used, as a validation tool, the Newcastle-Ottawa Scale (NOQAS) (Supplementary Tables S1 and S2) to categorize quality in four domains: participant selection, comparability of populations and outcome assessment. The methodological quality of the selected studies was assessed with an overall score ranging from 0 to 9 (highest level of quality). Study quality was classified according the study score into poor (0-3), moderate (4-6) and high (7-9) $[39,40]$. Poor methodological quality was not an exclusion criterion.

\subsection{Statistical and Sensitivity Analysis}

For all the meta-analytical procedures and graphical presentations, we used the meta, metafor, metagen and dmetar packages in R statistical software (version 4.1.1 with R-studio version 1.4.1717) in accordance with the guide by Harrer et al., 2019 [41]. When a significant Q-test [42] indicated heterogeneity across studies $(p<0.10)$ or the $I^{2}$ was above $50 \%$, the random-effects model was used for the meta-analysis; otherwise, the fixed-effect model was used [43]. The potential for publication bias and small-study effects were assessed visually 
by using funnel plots (1/standard error) by study effect size (mean difference). Egger's linear regression analyses were also used to further assess the presence of publication bias. A Baujat plot was used to detect outlier studies in our meta-analyses [44]. All the results were considered statistically significant when $p<0.05$, which may indicate publication bias [45]. To account for this, we performed the trim and fill method as described by Duval and Tweedie trim [46]. Further analysis was conducted to determine the influence of outliers on the pooled estimates using the dmetar R command [47].

For the sensitivity analyses, we performed the leave-one-out test [48]. After outlier studies were identified and excluded, a repeat meta-analysis was performed to assess the heterogeneity. To explain the residual heterogeneity and to assess the possible associations between population co-variables and study outcome, a random-effects univariate metaregression was performed to examine the association between the change in Legionella incidence and each of the following study-level variables (moderators): WHO region, study design and quality (NOQAS score) and healthcare setting. The case-control design, WHO region (Africa) and healthcare setting (outpatients with no comorbidities) were the reference categories. Furthermore, multivariate analyses were performed in a metaregression model [49]. The $p$-values for differences in the effects between the covariates were generated using the metagen function of $\mathrm{R}$ version 4.1.1.

\section{Results}

\subsection{Search Results and Study Selection}

Supplementary Figure S1 summarizes the results of the search strategy. A further explanation of the results, including study characteristics (Table S1), as outlined in Figure 1, is provided in the Supplementary Material. The results for 219 individual studies included in the meta-analysis are shown in Figure 2 and in Supplementary Table S2. Figure 2 shows that many countries did not have eligible studies, including countries that make up the whole of Eastern Europe, Africa, Central America and the Pacific Islands. These gaps highlighted the minimal data available to assess the burden of Legionella infection as a cause of CAP in low-income countries, because patients are sub-optimally treated for higher priority diseases, such as TB or HIV, at the time of admission [50]. Despite several published studies, there was also minimal data from the United Kingdom, Canada and the United States. The largest number of studies undertaken were in western Europe (59.2\%) with a bias towards Spain, which recorded 53 studies (24.2\%).

The median duration for all Legionella CAP studies considered was 23 months (interquartile range: $12-36$ months). The published studies were prospective studies $(n=173)$, retrospective studies $(n=33)$, cross sectional $(n=7)$ and case-control studies $(n=6)$. There were 139 studies that were based on hospital settings where patient populations were localized to a single city; 34 studies were based on records from multiple hospitals in different cities throughout a region; and 41 studies were multicenter studies representing the whole of a country (Canada, Spain, Slovenia, France, Switzerland, The Netherlands, Italy, Germany, Japan, Kuwait, Tunisia, Taiwan, South Korea, China, Chile, India, Vietnam, The Philippines and Singapore). Five large studies were multinational, and one was international, but the data from each country were not treated separately because the reported annual incidence of CAP caused by Legionella spp. was extremely low, ranging from $0.001-0.6$ per 100,000 population in these studies [51-56]. The study size ranged from 15 to 7803 patients, with a median of 232 (interquartile range: 133-474) enrolled patients.

Most studies specified some exclusion criteria, generally related to (a) pneumonia not being the primary cause for hospital admission; (b) lung cancer or terminal illness; (c) distal to bronchial obstruction; (d) patients who had been in hospital within the previous 14 days, who were immunocompromised and (e) nursing home residents. We extracted data on the study country, sample size, diagnostic test used and age range for CAP studies, and the number of people with LD. This systematic review considered studies of CAP patients of all ages, as well as patients with tuberculosis or human immunodeficiency virus (HIV) infection. 


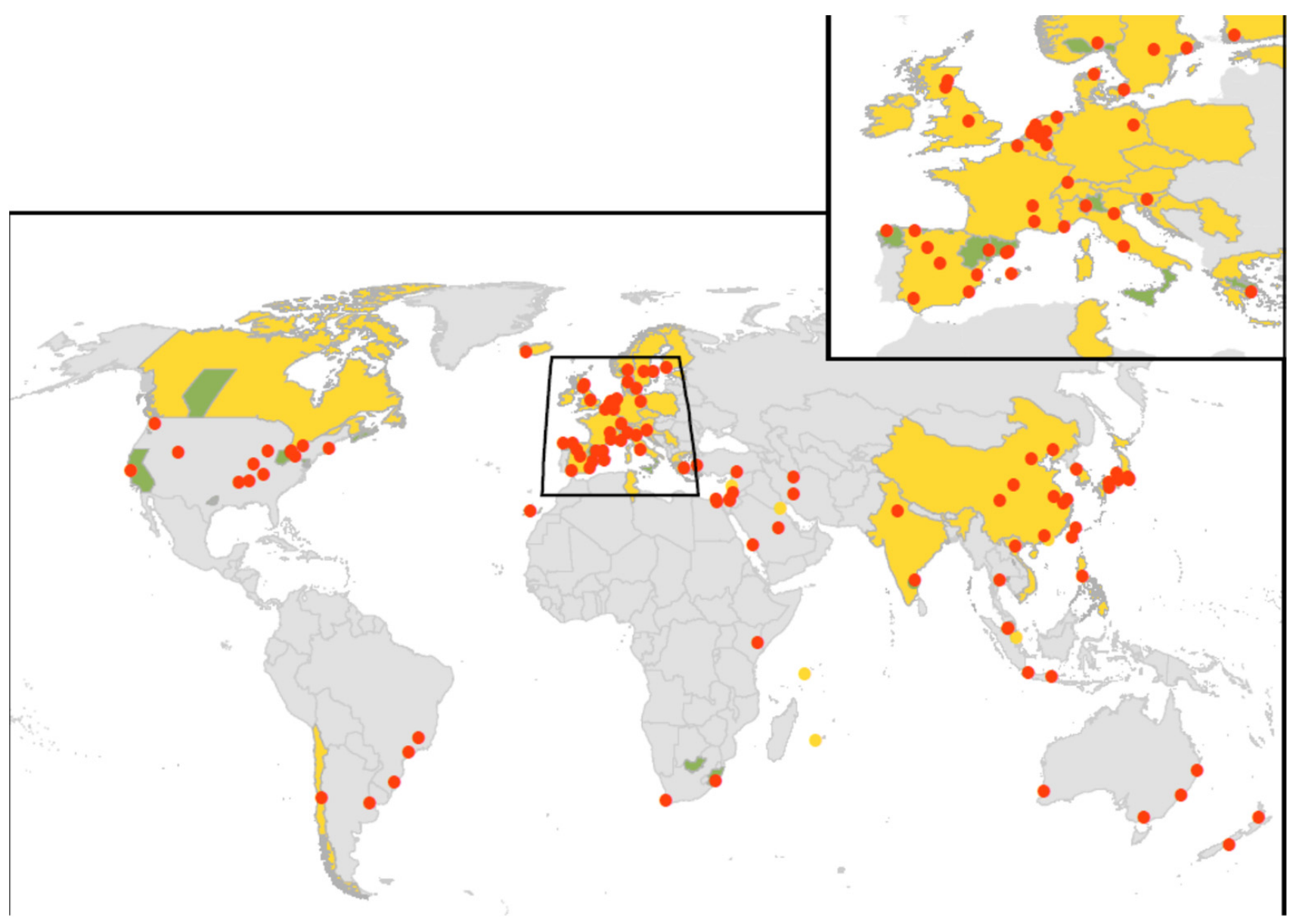

Figure 2. Spatial distribution of CAP studies. Studies based on representative population sampling are considered as representative (yellow). Studies based on the records from multiple hospitals in different cities and studies based on records from laboratories that perform diagnostic testing for Legionella for patients throughout a region or country are considered as non-representative (green). Studies based in hospital settings whose patient populations are localized to a single city are considered localized (red points).

Three studies observed a significant correlation between the lowest seasonal average temperature and polymicrobial pneumonia and pneumococcal pneumonia; conversely, $L$. pneumophila was more common when the temperatures were higher $[2,3,9]$.

\subsection{Legionella Epidemiology}

Based on an R command for the overall effect size, the proportion of Legionella spp. as the causative agent of CAP during the study period was 4.6\% (95\% CI: 4.4-4.7) (Table 1), with the highest proportion recorded in Eastern Mediterranean (9.7\% 95\% CI 8.5-10.9). Of the healthcare settings, ICU patients only recorded the highest proportion of Legionella spp. as the causative agent of CAP (9\% 95\% CI 3-14). Supplementary Table S2 and Figure S3 show that the annual incidence of Legionella infection, because of its global distribution, was highly variable in different studies, ranging from 0.001 and 147.4 per 100,000 population of CAP (the mean incidence rate was 2.8 per 100,000 for all regions (Table 1); $56.2 \%$ of the studies reported an annual incidence of $<0.49^{\prime}$; and $37 \%$ of studies reported an annual incidence of $\leq 0.10$, Figure 3 ) identified in studies, which had recruited patients from 1 January 1990 (Supplementary Table S2). 
Table 1. Summary of the contribution of Legionella spp. to CAP, CAP rates, and estimated Legionella rates globally and by the WHO region together with the confidence intervals.

\begin{tabular}{|c|c|c|c|c|c|c|c|}
\hline $\begin{array}{l}\text { WHO } \\
\text { Region }\end{array}$ & \#Cases/\#Participants & $\begin{array}{c}\text { Legionella } \\
\text { Proportion } \\
(\%)\end{array}$ & $95 \% \mathrm{CI}$ & $\begin{array}{c}\text { CAP Rate } \\
(\text { per } 100,000)\end{array}$ & $95 \% \mathrm{CI}$ & $\begin{array}{c}\text { Legionella } \\
\text { Rate (per } \\
100,000)\end{array}$ & $95 \% \mathrm{CI}$ \\
\hline All Regions & $5723 / 125,764$ & 4.6 & $(4.4-4.7)$ & 46.7 & $(46.6-46.8)$ & 2.8 & $(2.7-2.9)$ \\
\hline Africa & $48 / 2965$ & 1.6 & $(1.1-2.1)$ & 31.5 & $(30.1-32.4)$ & 0.9 & $(0.1-1.8)$ \\
\hline $\begin{array}{l}\text { Eastern } \\
\text { Mediter- } \\
\text { ranean }\end{array}$ & $248 / 2556$ & 9.7 & $(8.5-10.9)$ & 65.1 & $(64.7-65.5)$ & 13.9 & $(13.5-14.3)$ \\
\hline Europe & $2529 / 56,537$ & 4.5 & $(4.3-4.6)$ & 62.9 & $(62.8-63.0)$ & 2.4 & $(2.3-2.5)$ \\
\hline $\begin{array}{l}\text { South-East } \\
\text { Asian }\end{array}$ & $228 / 5267$ & 4.3 & $(3.7-4.9)$ & 132.7 & $\begin{array}{l}(132.3- \\
133.1)\end{array}$ & 3.4 & $(2.9-3.8)$ \\
\hline $\begin{array}{l}\text { The } \\
\text { Americas }\end{array}$ & $437 / 29,628$ & 1.5 & $(1.3-1.6)$ & 74.0 & $(73.7-74.3)$ & 1.6 & $(1.3-1.9)$ \\
\hline $\begin{array}{l}\text { Western } \\
\text { Pacific }\end{array}$ & $1120 / 25,109$ & 4.5 & $(4.2-4.7)$ & 17.3 & $(17.1-17.5)$ & 0.7 & $(0.5-0.9)$ \\
\hline
\end{tabular}

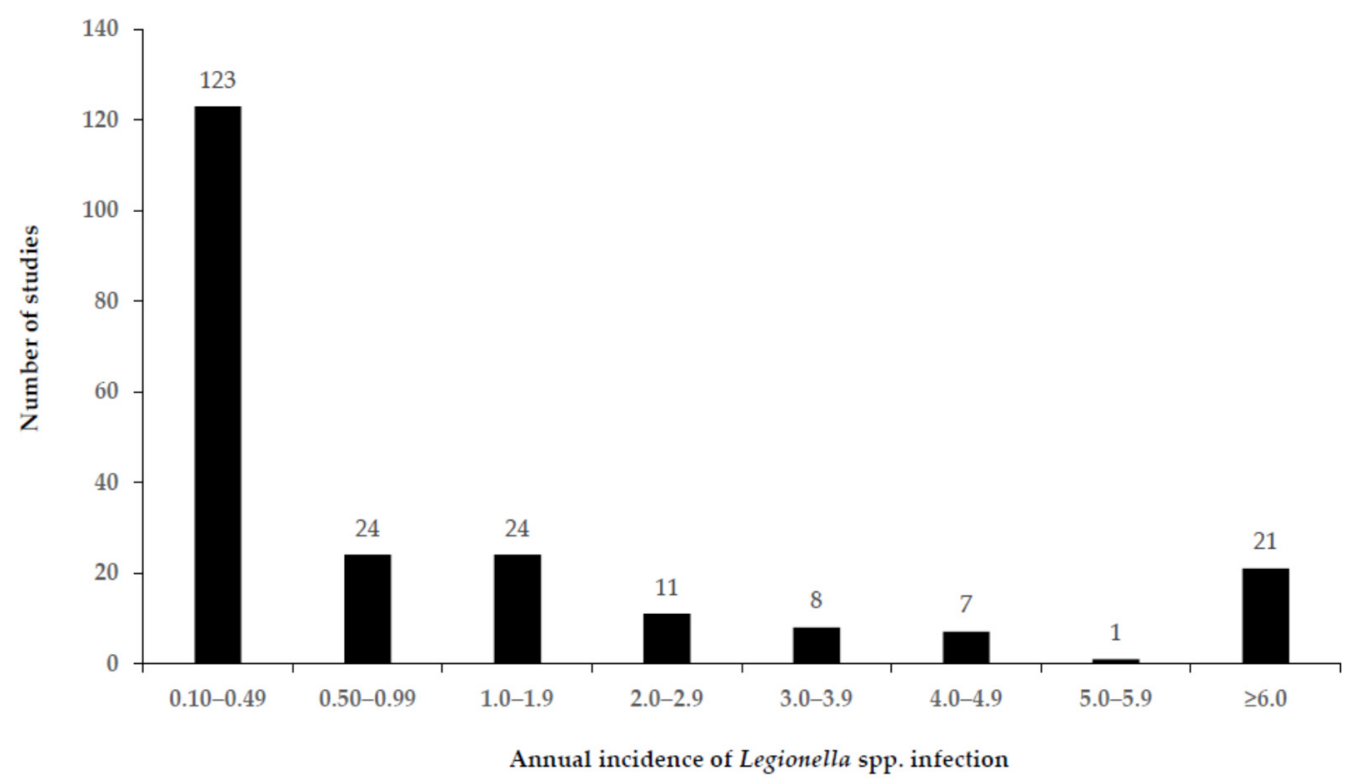

Figure 3. Annual incidence of Legionella spp. infection (cases/100,000 population) among CAP patients (all ages) from 219 included studies for meta-analysis.

Of the 196 studies that recorded the Legionella spp. detected, L. pneumophila was identified as the causative pathogen in $95.4 \%$ of the studies of patients with CAP requiring hospitalization and was associated with high morbidity. Non-pneumophila Legionella spp. represented only $4.6 \%$ (L. longbeachae $3.1 \%$ ) of the etiology detected in the 125,764 patients with CAP. As a result of the high frequency of respiratory failure, patients with Legionella CAP are significantly more likely to be admitted to an intensive care unit [57]. The mean CFR was $22.6 \%(S D \pm 39.5)$, which was similar to the CFR in healthcare associated cases of $18 \%$ [58]-31.7\% reported in the literature [59]. The median proportion of males in the 179 studies that reported sex was 128 (71.5\%).

\subsection{Sensitivity Analyses}

Table 1 presents a summary of the studies showing the proportions of Legionella spp. as the causative agent for CAP. There was significant heterogeneity across all the 
studies that met the criteria $\left(I^{2}=99.27 \%(p<0.0001)\right.$, (Table 2$)$. Africa was the only region in which there was moderate heterogeneity observed for both random-effects and fixed-effects models (Table 2). Figures S4-S9 show each of the forest plots by the WHO region. Observational studies reported major differences in the frequencies of Legionella spp. causing CAP. These differences may be due to the variances in the locations studied, the specific patient populations included and the extent and nature of the diagnostic tests used. Using the Baujat plot and the 'find.outliers' function from the dmetar package to identify the outliers (Figure S10), we re-ran our initial analysis by excluding the identified outliers. The overall heterogeneity was substantially reduced $\left(I^{2}=43.53 \%\right)$.

Table 2. Summary of sensitivity analyses.

\begin{tabular}{|c|c|c|c|c|c|c|}
\hline $\begin{array}{l}\text { Description } \\
\text { (WHO Region) }\end{array}$ & \#Cases/\#Participants & $\begin{array}{l}\text { Pool Effect } \\
\text { Estimate }\end{array}$ & $95 \% \mathrm{CI}^{1}$ & $I^{2}(\%)$ & $\begin{array}{c}p \text {-Value for } \\
\text { Heterogeneity }\end{array}$ & Model \\
\hline All Regions & $5723 / 125,764$ & 0.05 & $(0.04-0.06)$ & $99.27 \%$ & $<0.0001$ & Random-effects \\
\hline Africa & $48 / 2965$ & 0.02 & $\begin{array}{l}(0.01-0.03) \\
(0.01-0.03) \\
\end{array}$ & & $\begin{array}{l}0.1092 \\
0.1092\end{array}$ & $\begin{array}{l}\text { Random-effects } \\
\text { Fixed-effects }\end{array}$ \\
\hline $\begin{array}{l}\text { Eastern } \\
\text { Mediterranean }\end{array}$ & $248 / 2556$ & 0.09 & $(0.04-0.06)$ & & $<0.0001$ & Random-effects \\
\hline Europe & $2529 / 56,537$ & 0.06 & $(0.04-0.06)$ & & $<0.0001$ & Random-effects \\
\hline $\begin{array}{l}\text { South-East } \\
\text { Asian }\end{array}$ & $228 / 5267$ & 0.07 & $(0.04-0.06)$ & & $<0.0001$ & Random-effects \\
\hline The Americas & $437 / 29,628$ & 0.03 & $(0.04-0.06)$ & & $<0.0001$ & Random-effects \\
\hline Western Pacific & $1120 / 25,109$ & 0.02 & $(0.04-0.06)$ & & $<0.0001$ & Random-effects \\
\hline
\end{tabular}

${ }^{1} \mathrm{CI}$, confidence interval.

\subsection{Univariate and Multivariate Meta-Regression}

Taken together, the univariate meta-regression showed no significant association between the changes in Legionella incidence and study design, WHO region, study quality (overall) and healthcare setting (Table 3). There was an exception for the Eastern Mediterranean region, a significant moderator of the $\mathrm{WHO}$ region. Slope coefficients did not differ significantly from zero $(p>0.05)$.

Similar to the univariate model, the multivariate meta-regression did not reveal any significant change between Legionella incidence and study design, WHO region, study quality (overall) and healthcare setting, except for the Eastern Mediterranean region (WHO region) (Table 3). 
Table 3. Univariate and multivariate meta-regression for change in Legionella incidence involving several study characteristics.

\begin{tabular}{|c|c|c|c|c|c|c|c|c|c|c|c|}
\hline $\begin{array}{l}\text { Univariate } \\
\text { Analysis }\end{array}$ & Covariate & $\begin{array}{l}\text { Number of } \\
\text { Studies }\end{array}$ & $\beta$-Coefficient & $95 \% \mathrm{CI}$ & $p$-Value & $\begin{array}{l}\text { Heterogeneity } \\
\left(I^{2}\right)(\%)\end{array}$ & $\begin{array}{l}\text { Multivariate } \\
\text { Analysis }\end{array}$ & $\beta$-Coefficient & $95 \%$ CI & $p$-Value & $\begin{array}{c}\text { Heterogeneity } \\
\left(I^{2}\right)(\%)(\text { For } \\
\text { Full } \\
\text { Multivariate } \\
\text { Model }\end{array}$ \\
\hline & \multicolumn{11}{|l|}{ Study Design } \\
\hline & Cross sectional & 7 & 0.0111 & $\begin{array}{l}-0.0535 \text { to } \\
0.0756\end{array}$ & 0.7368 & $99.15 \%$ & & 0.0042 & $\begin{array}{c}-0.0579 \text { to } \\
0.0663\end{array}$ & 0.8949 & $98.40 \%$ \\
\hline & Prospective & 173 & -0.0287 & $\begin{array}{c}-0.0765 \text { to } \\
0.0190\end{array}$ & 0.2380 & & & -0.0298 & $\begin{array}{c}-0.0771 \text { to } \\
0.0175\end{array}$ & 0.2167 & \\
\hline & Retrospective & 33 & -0.0063 & $\begin{array}{l}-0.0571 \text { to } \\
0.0445\end{array}$ & 0.8082 & & & 0.0005 & $\begin{array}{c}-0.0492 \text { to } \\
0.0501\end{array}$ & 0.9855 & \\
\hline & \multicolumn{6}{|l|}{ WHO Region } & & & & & \\
\hline & $\begin{array}{l}\text { Eastern } \\
\text { Mediter- } \\
\text { ranean }\end{array}$ & 15 & 0.0706 & $\begin{array}{l}0.0213 \text { to } \\
0.1199\end{array}$ & 0.0050 & $98.83 \%$ & & 0.0633 & $\begin{array}{c}0.0099 \text { to } \\
0.1167\end{array}$ & 0.0201 & \\
\hline & European & 117 & 0.0376 & $\begin{array}{l}-0.0049 \text { to } \\
0.0801\end{array}$ & 0.0830 & & & 0.0296 & $\begin{array}{c}-0.0168 \text { to } \\
0.0760\end{array}$ & 0.2109 & \\
\hline & $\begin{array}{l}\text { South-East } \\
\text { Asian }\end{array}$ & 12 & 0.0465 & $\begin{array}{l}-0.0043 \text { to } \\
0.0973\end{array}$ & 0.0730 & & & 0.0448 & $\begin{array}{c}-0.0119 \text { to } \\
0.1016\end{array}$ & 0.1217 & \\
\hline & The Americas & 31 & 0.0238 & $\begin{array}{l}-0.0214 \text { to } \\
0.0690\end{array}$ & 0.3023 & & & 0.0157 & $\begin{array}{c}-0.0331 \text { to } \\
0.0645\end{array}$ & 0.5287 & \\
\hline & $\begin{array}{l}\text { Western } \\
\text { Pacific }\end{array}$ & 38 & 0.0152 & $\begin{array}{l}-0.0292 \text { to } \\
0.0595\end{array}$ & 0.5024 & & & 0.0124 & $\begin{array}{c}-0.0358 \text { to } \\
0.0606\end{array}$ & 0.6139 & \\
\hline & \multicolumn{6}{|c|}{ Study Quality Assessment } & & & & & \\
\hline & Overall & 219 & -0.0001 & $\begin{array}{c}-0.0048 \text { to } \\
0.0046\end{array}$ & 0.9655 & $99.23 \%$ & & -0.0005 & $\begin{array}{c}-0.0053 \text { to } \\
0.0043\end{array}$ & 0.8457 & \\
\hline & \multicolumn{6}{|c|}{ Healthcare Setting } & & & & & \\
\hline & $\begin{array}{l}\text { Outpatients } \\
\text { (with } \\
\text { comorbidities) }\end{array}$ & 5 & -0.0020 & $\begin{array}{l}-0.0571 \text { to } \\
0.0532\end{array}$ & 0.9446 & $99.01 \%$ & & -0.0024 & $\begin{array}{l}-0.0554 \text { to } \\
0.0505\end{array}$ & 0.9285 & \\
\hline & $\begin{array}{l}\text { Inpatients (no } \\
\text { ICU) }\end{array}$ & 157 & 0.0167 & $\begin{array}{c}-0.0186 \text { to } \\
0.0520\end{array}$ & 0.3531 & & & 0.0107 & $\begin{array}{c}-0.0234 \text { to } \\
0.0449\end{array}$ & 0.5376 & \\
\hline & $\begin{array}{l}\text { ICU patients } \\
\text { only }\end{array}$ & 18 & 0.0397 & $\begin{array}{l}-0.0021 \text { to } \\
0.0532\end{array}$ & 0.0624 & & & 0.0352 & $\begin{array}{c}-0.0054 \text { to } \\
0.0759\end{array}$ & 0.0893 & \\
\hline
\end{tabular}




\subsection{Publication Bias}

The $p$-value for the Egger's test confirmed that there was significant bias and therefore publication bias $(p \leq 0.0001)$. The funnel plot (Figure S11-WHO region (European) study Tilley 2009 was identified as the key outlier in the funnel plot) appears as asymmetrical and suggestive of publication bias, which cannot be completely excluded as a factor of influence on the present meta-analyses. After small population studies were excluded, the trim and fill method result did not change the parameter estimates for Legionella's contribution to CAP (Figure S12).

\section{Discussion}

This meta-analysis found that on average, $4.6 \%$ of CAP was caused by Legionella species. Consequently, the mean incidence rate of Legionella infection was 2.8/100,000 population. The mean CFR was $22.6 \%$, which may be an over-estimate as Legionella infection is an underdiagnosed disease [59].

The large heterogeneity observed in the incidence estimates for Legionella infections is not unexpected considering the multitude of potential sources of the measurement error, including the variable definitions of CAP, patients' characteristics, diagnostic methods and criteria used for diagnosis. For example, there was an impact of small studies $(19.2 \%$ had a size of less than 100 patients) with a higher proportion of Legionella in areas where it was anticipated it would be more severe, namely those patients admitted to ICU (9\%: 95\% CI 0.03-0.14). The CAP etiologies were determined via a range of diagnostic tests, including culture, urine antigen, serology and molecular nucleic acid testing (Table S2). Over half of the studies (57.2\%) that examined the etiology of Legionella in CAP used urinary antigen assays to identify the organism. Fifty-two percent of the studies that used sputum culture, also reported in their microbiological evaluation some quality criteria to improve reliability, although the criteria used varied.

The knowledge of pathogens causing CAP is important for the selection of antimicrobial treatment [9]. Despite the differences in geographic location, patient population and laboratory methods applied, this systematic review with meta-analysis represents a synthesis of published CAP etiology studies revealing several important findings: (i) Legionella spp. were found to be a common bacterial etiology of CAP (4.6\%: 95\% CI 4.4-4.7). (ii) The annual incidence of Legionella infection, in spite of its global diffusion, was highly variable in different studies (Figure 3). This present study provides an estimate of the mean incidence of Legionella infection in CAP, which could be used to estimate the global public health burden of LD to support improved prevention and management interventions. (iii) L. pneumophila was identified as an important agent for severe CAP after S. pneumoniae. This result is in line with global findings [13,60-62], although one study found no L. pneumophila positive cases among 373 patients but detected L. longbeachae infection in $3.8 \%$ of patients using serology and PCR [63].

The spatial differences in the importance of non-pneumophila Legionella spp. as pathogens are under-recognized, in part due to the available diagnostic tests, such as the urinary antigen test that is biased towards the detection only of L. pneumophila serogroup 1 infections $[10,11]$. The widespread introduction of Legionella urine antigen testing into hospital laboratories, globally has resulted in a decline in the use of culture or other serological tests [64]. Some authors suggested that the total reliance on this diagnostic test may miss up to $40 \%$ of LD cases [16], while others recommended that it should be used routinely in those with severe CAP and/or associated epidemiological factors, such as during an outbreak or post travel [65]. In addition, the non-pneumophila species, such as L. longbeachae, does not grow on blood agar media and is usually not detected by sputum Gram-stain or blood culture [66]. Yet, in countries, such as New Zealand, Australia and Scotland, species, including L. longbeachae and other non-pneumophila Legionella spp., are the more prevalent causes of infection for which serology or PCR may be used as the primary diagnostic test [23]. Since none of the current diagnostic tests to detect Legionella infection have sufficient sensitivity to guide definitive therapy for CAP, clinicians must treat possible Legionella 
infections empirically [67]. (iv) Seasonal variation was observed for L. pneumophila infection in CAP with the risk being lower in winter and spring than in summer [2,9]. As a result, there is a perception that Legionella is more important in Mediterranean countries and is uncommon in northern or southern temperate zones, other than in travelers from these countries or in the context of a local source of infection via an outbreak [11].

The main limitation of this study is the absence of data from large parts of the world, and the small number of patients enrolled from countries representing Africa and Asia, countries with the highest pneumonia burden. As a result, this limited the generalizability of our findings. We attempted to reduce bias by including both English and non-English studies and by attempting to identify cases of multiple publication. Overall, the heterogeneity of studies was high $\left(I^{2}=99.27 \%\right)$, which led us to explore whether there were potential contributors for such heterogeneity. We thus performed an exclude-one sensitivity analysis and examined the impact of outliers to locate the source of heterogeneity and rectify this, which resulted in a decrease in heterogeneity $\left(I^{2}=43.53 \%\right)$.

As part of the burden of respiratory infection, CAP is well recognized to be a leading cause. No detrimental effects of increased Legionella incidence could be observed in the metaregression possibly owing to the low number of studies, many countries having no eligible studies and the inherent biases of the method. Therefore, any findings should be interpreted with caution. We included studies in which the outcome measures and definitions were based on defined criteria [68], including the acknowledgement that there is no consensus on what precise criteria are essential for the diagnosis of pneumonia [69]. Therefore, we did not exclude the studies in which a radiographic confirmation of pneumonia was an inclusion criterion to confirm and validate each case of CAP, particularly since several studies demonstrated a lack of agreement in the interpretation of chest radiographs bringing their role as the ultimate arbiter of CAP diagnosis into question [70]. Nevertheless, we anticipate that there may have been patients in whom the diagnosis may have been missed, particularly among those with milder symptoms, who were treated for CAP in a community setting. Few studies have focused on patients with pneumonia in primary care, in which Legionella among outpatients was found to be uncommon [71-74], although there are exceptions (von Baum et al., 2008) [13]. During a three-year period, only one known case of L. pneumophila infection occurred in the catchment area of a Swedish primary care center, but this patient was referred to and treated in the nearby hospital [75]. A limitation of these studies was that the etiology of pneumonia was determined by testing acute and convalescent serum samples for antibodies to Legionella. While once popular, globally one of the criticisms now leveled at serology, its use has significantly declined because it is not regarded as a useful rapid diagnostic method [76], compared to molecular methods, such as the polymerase chain reaction (PCR), which is increasingly being used in routine practice in many clinical settings due to more robust assays for the detection of other diseases in addition to Legionella [77]. The principal limitation of this study is the heterogeneity of the microbiological data (samples from different origins and diagnostic tests with different targets). In some studies, several methods were used to reach an etiologic diagnosis (for example, UAT, PCR, serology, and culture for Legionella), which made it difficult to determine what the number of patients had tested positive for each method.

The Community-Acquired Pneumonia Organization initiative may offer a platform to investigators from Africa and Asia, to address some of the research questions in the area of Legionella in the pneumonia of HIV-infected patients [48] although one study found that Legionella spp. were a leading cause of CAP among HIV-negative patients [78]. Epidemiological factors, such as the time of year, may have also impacted the frequency of Legionella cases detected in CAP. The disease's seasonality is known to increase the risk of infection, with most cases being reported during warm and humid weather, which tends to support pathogen survival, growth and the potential for aerosol exposures, increasing disease risk [78]. The median study duration for the studies included in our analysis was 23 months, which may not have been long enough to capture the long-term seasonal effects. 


\section{Conclusions}

We performed a systematic review and meta-analysis using appropriate methodology but relied on data that are difficult to interpret mainly due to their methodological differences. Nevertheless, this review provided the first estimate of the mean incidence of Legionella infection in CAP, which can be used to estimate the regional and global burden of LD.

Supplementary Materials: The following are available online at https:/ /www.mdpi.com/article/10 .3390/ijerph19031907/s1: Figure S1: The PRISMA checklist; Figure S2: Search strategy for community acquired pneumonia and Legionella; Table S1: Study characteristics summary included in the metaanalysis; Table S2: Studies of patient recruitment from 1 January 1990 defining the etiology of community-acquired pneumonia (CAP) and Legionella according to WHO region; Table S3: Patient and study characteristics of included studies where Legionella was not detected as the cause of infection; Table S4: Patient and study characteristics of excluded studies from the meta-analysis that reported data on overlapping participant populations; Figure S3: Legionella incidence of CAP studies, which recruited patients from 1 January 1990; Figure S4: Forest plot of European studies showing proportions of Legionella as the causative agent to CAP; Figure S5: Forest plot of Eastern Mediterranean studies showing the proportions of Legionella as the causative agent to CAP; Figure S6: Forest plot of African studies showing the proportions of Legionella as the causative agent to CAP; Figure S7: Forest plot of Western Pacific studies showing the proportions of Legionella as the causative agent to CAP; Figure S8: Forest plot of South-East Asian studies showing the proportions of Legionella as the causative agent to CAP; Figure S9: Forest plot of The Americas studies showing the proportions of Legionella as the causative agent to CAP; Figure S10: Baujat plot; Figure S11: Funnel plot to evaluate publication bias (all studies) and Figure S12: Funnel plot (trim and fill).

Author Contributions: F.F.G. conceived the study and planned the review. F.F.G. searched the literature and complied the list of articles. F.F.G. downloaded the full reports and reviewed, extracted, and analyzed the data in consultation with S.H. and P.W. N.F. carried out the meta-analyses. F.F.G. wrote the first draft of the report with revisions and input from S.H., P.W., N.F. and M.G.B. All authors have read and agreed to the published version of the manuscript.

Funding: This research received no external funding.

Institutional Review Board Statement: Not applicable.

Informed Consent Statement: Not applicable.

Data Availability Statement: Further information can be obtained from the corresponding author.

Acknowledgments: The library staff from the New Zealand Ministry of Health and the University of Otago, Wellington provided valuable help in obtaining articles and assisted with the literature search. Maki Okubo assisted with translating some of the Japanese papers. Andrew Parnell assisted in the construction of the map using ArcGIS. While every effort has been made to ensure the information in this report is accurate, the authors do not accept any responsibility or liability for error of fact, omission, interpretation, or opinion that may be present, nor for the consequences of any decisions based on this information.

Conflicts of Interest: The authors declare no conflict of interest.

\section{References}

1. Vos, T.; Barber, R.; Bell, B.; Bertozzi-Villa, A.; Biryukov, S.; Bolliger, I.; Charlson, F.; Davis, A.; Degenhardt, L.; Dicker, D. Global Burden of Disease Study 2013 Collaborators. Global, regional, and national incidence, prevalence, and years lived with disability for 301 acute and chronic diseases and injuries in 188 countries, 1990-2013: A systematic analysis for the Global Burden of Disease Study 2013. Lancet 2015, 386, 743-800.

2. Herrera-Lara, S.; Fernández-Fabrellas, E.; Cervera-Juan, Á.; Blanquer-Olivas, R. Do seasonal changes and climate influence the etiology of community acquired pneumonia? Arch. Bronconeumol. 2013, 49, 140-145. [CrossRef]

3. Valcina, O.; Pūle, D.; Lucenko, I.; Krastina, D.; Šteingolde, Ž.; Krūmina, A.; Bērzinšš, A. Legionella pneumophila SeropositivityAssociated Factors in Latvian Blood Donors. Int. J. Environ. Res. Public Health 2015, 13, 58. [CrossRef] [PubMed] 
4. $\quad$ Niederman, M.S.; Mandell, L.A.; Anzueto, A.; Bass, J.B.; Broughton, W.A.; Campbell, G.D.; Dean, N.; File, T.; Fine, M.J. Guidelines for the management of adults with community- acquired pneumonia: Diagnosis, assessment of severity, antimicrobial therapy, and prevention. Am. J. Respir. Crit. Care Med. 2001, 163, 1730-1754. [CrossRef] [PubMed]

5. Jain, S.; Self, W.H.; Wunderink, R.G.; Fakhran, S.; Balk, R.; Bramley, A.M.; Reed, C.; Grijalva, C.G.; Anderson, E.J.; Courtney, D.M.; et al. Community-acquired pneumonia requiring hospitalization among US adults. N. Engl. J. Med. 2015, 373, 415-427. [CrossRef]

6. Johansson, N.; Kalin, M.; Tiveljung-Lindell, A.; Giske, C.G.; Hedlund, J. Etiology of community-acquired pneumonia: Increased microbiological yield with new diagnostic methods. Clin. Infect. Dis. 2010, 50, 202-209. [CrossRef]

7. Huijskens, E.G.; Koopmans, M.; Palmen, F.M.; van Erkel, A.J.; Mulder, P.G.; Rossen, J.W. The value of signs and symptoms in differentiating between bacterial, viral and mixed aetiology in patients with community-acquired pneumonia. J. Med. Microbiol. 2014, 63, 441-452. [CrossRef]

8. Cilloniz, C.; Martin-Loeches, I.; Garcia-Vidal, C.; San Jose, A.; Torres, A. Microbial etiology of pneumonia: Epidemiology, diagnosis and resistance patterns. Int. J. Mol. Sci. 2016, 17, 2120. [CrossRef]

9. Stout, J.E.; Yu, V.L. Legionellosis. N. Engl. J. Med. 1997, 337, 682-687. [CrossRef] [PubMed]

10. Woodhead, M. Community-acquired pneumonia in Europe: Causative pathogens and resistance patterns. Eur. Respir. J. 2002, 20, 20s-27s. [CrossRef]

11. Garau, J.; Calbo, E. Community-acquired pneumonia. Lancet 2008, 371, 455-458. [CrossRef]

12. Cunha, B. The atypical pneumonias: Clinical diagnosis and importance. Clin. Microbiol. Infect. 2006, 12, 12-24. [CrossRef] [PubMed]

13. von Baum, H.; Ewig, S.; Marre, R.; Suttorp, N.; Gonschior, S.; Welte, T.; Lück, C. Community-acquired Legionella pneumonia: New insights from the German competence network for community acquired pneumonia. Clin. Infect. Dis. 2008, 46, 1356-1364. [CrossRef]

14. Tasci, S.S.; Kavalci, C.; Kayipmaz, A.E. Relationship of meteorological and air pollution parameters with pneumonia in elderly patients. Emerg. Med. Int. 2018, 2018, 4183203. [CrossRef] [PubMed]

15. Cilloniz, C.; Ewig, S.; Gabarrus, A.; Ferrer, M. Seasonality of pathogens causing community-acquired pneumonia. Respirology 2017, 22, 778-785. [CrossRef] [PubMed]

16. Fields, B.S.; Benson, R.F.; Besser, R.E. Legionella and Legionnaires' disease: 25 years of investigation. Clin. Microbiol. Rev. 2002, 15, 506-526. [CrossRef]

17. Carratala, J.; Garcia-Vidal, C. An update on Legionella. Curr. Opin. Infect. Dis. 2010, 23, 152-157. [CrossRef]

18. Edelstein, P.H. Legionnaires' disease. Clin. Infect. Dis. 1993, 16, 741-747. [CrossRef]

19. Roig, J.; Domingo, C.; Morera, J. Legionnaires' disease. Chest 1994, 105, 1817-1825. [CrossRef]

20. Luck, P.C.; Helbig, J.H. Epidemiology of legionellosis. Schriftenr. Ver. Wasser. Boden. Lufthyg. 1993, 91, 41-58.

21. Little, K. Legionellosis: Epidemiology, management and prevention. Nurs. Times 2003, 99, 28-29. [PubMed]

22. Eickhoff, T.C. Epidemiology of Legionnaires' disease. Ann. Intern. Med. 1979, 90, 499-502. [CrossRef] [PubMed]

23. Phin, N.; Parry-Ford, F.; Harrison, T.; Stagg, H.R.; Zhang, N.; Kumar, K.; Lortholary, O.; Zumla, A.; Abubakar, I. Epidemiology and clinical management of Legionnaires' disease. Lancet Infect. Dis. 2014, 14, 1011-1021. [CrossRef]

24. Peto, L.; Nadjm, B.; Horby, P.; Ngan, T.T.; van Doorn, R.; Kinh, N.V.; Wertheim, H.F. The bacterial aetiology of adult communityacquired pneumonia in Asia: A systematic review. Trans. R. Soc. Trop. Med. Hyg. 2014, 108, 326-337. [CrossRef]

25. Marchello, C.; Dale, A.P.; Thai, T.N.; Han, D.S.; Ebell, M.H. Prevalence of Atypical Pathogens in Patients With Cough and Community-Acquired Pneumonia: A Meta-Analysis. Ann. Fam. Med. 2016, 14, 552566. [CrossRef] [PubMed]

26. Graham, F.F.; Hales, S.; White, P.S.; Baker, M.G. Review Global seroprevalence of legionellosis-a systematic review and metaanalysis. Sci. Rep. 2020, 10, 7337. [CrossRef] [PubMed]

27. Lim, W.; Macfarlane, J.; Boswell, T.; Harr ison, T.G.; Rose, D.; Leinonen, M.; Saikku, P. Study of community acquired pneumonia aetiology (SCAPA) in adults admitted to hospital: Implications for management guidelines. Thorax 2001, 56, 296-301. [CrossRef]

28. Stroup, D.F.; Berlin, J.A.; Morton, S.C.; Olkin, I.; Williamson, G.D.; Rennie, D.; Moher, D.; Becker, B.; Sipe, T.A.; Thacker, S.B. Meta-analysis of observational studies in epidemiology: A proposal for reporting. JAMA 2000, 283, 2008-2012. [CrossRef]

29. Liberati, A.; Altman, D.G.; Tetzlaff, J.; Mulrow, C.; Gøtzsche, P.C.; Ioannidis, J.P.; Clarke, M.; Devereaux, P.J.; Kleijnen, J.; Moher, D. The PRISMA statement for reporting systematic reviews and meta-analyses of studies that evaluate healthcare interventions: Explanation and elaboration. BMJ 2009, 62, e1-e34. [CrossRef]

30. Google Inc. Goggle Translate. 2017. Available online: https://translate.google.com.au/ (accessed on 30 April 2021).

31. Shindo, Y.; Ito, R.; Kobayashi, D.; Ando, M.; Ichikawa, M.; Shiraki, A.; Goto, Y.; Fukui, Y.; Iwaki, M.; Okumura, J.; et al. Risk factors for drug-resistant pathogens in community-acquired and healthcare-associated pneumonia. Am. J. Respir Crit. Care Med. 2013, 188, 985-995. [CrossRef]

32. Dahmash, N.S.; Chowdhury, M.N. Re-evaluation of pneumonia requiring admission to an intensive care unit: A prospective study. Thorax 1994, 49, 71-76. [CrossRef]

33. Ben-Dror, G.; Mizerizky, Y.; Viar, G.; Zuker, M.; Miron, D. The epidemiology and clinical features of Legionella pneumonia (LP) in patients older than 60 years old who were hospitalized with pneumonia in northern Israel. Harefuah 2002, 141, 680-682. [PubMed]

34. Hollenbeck, B.; Dupont, I.; Mermel, L.A. How often is a work-up for Legionella pursued in patients with pneumonia? a retrospective study. BMC Infect. Dis. 2011, 11, 237. [CrossRef] [PubMed] 
35. Doaa, A.A.-A.; Fatma, A.A.; Ramadan, M.N.; Raghda, H. Prevalence of Legionella among pneumonia patients and environmental water samples in an Egyptian University Hospital. Int. Arabic. J. Antimicrob. Agents 2016, 6, 1-11. [CrossRef]

36. Jokinen, C.; Heiskanen, L.; Juvonen, H.; Kallinen, S.; Kleemola, M.; Koskela, M.; Leinonen, M.; Rönnberg, P.R.; Saikku, P.; Stén, M.; et al. Microbial etiology of community-acquired pneumonia in the adult population of 4 municipalities in eastern Finland. Clin. Infect. Dis. 2001, 32, 1141-1154. [CrossRef] [PubMed]

37. Hohenthal, U.; Vainionpää, R.; Meurman, O.; Vahtera, A.; Katiskalahti, T.; Nikoskelainen, J.; Kotilainen, P. Aetiological diagnosis of community acquired pneumonia: Utility of rapid microbiological methods with respect to disease severity. Scand. J. Infect. Dis. 2008, 4, 131-138. [CrossRef]

38. Cillóniz, C.; Dominedò, C.; Nicolini, A.; Torres, A. PES pathogens in severe community-acquired pneumonia. Microorganisms 2019, 7, 49. [CrossRef] [PubMed]

39. Stang, A. Critical evaluation of the Newcastle-Ottawa scale for the assessment of the quality of nonrandomized studies in meta-analyses. Eur. J. Epidemiol. 2010, 25, 603-605. [CrossRef]

40. Herzog, R.; Alvarez-Pasquin, M.J.; Diaz, C.; Del Barrio, J.L.; Estrada, J.M.; Gil, Á. Are healthcare workers' intentions to vaccinate related to their knowledge, beliefs and attitudes? A systematic review. BMC Public Health 2013, 13, 154. [CrossRef]

41. Harrer, M.; Cuijpers, P.; Furukawa, T.A.; Ebert, D.D. Doing Meta-Analysis in R: A Hands-On Guide. 2019. Available online: https:/ / bookdown.org/MathiasHarrer/Doing_Meta_Analysis_in_R/ (accessed on 30 March 2021).

42. Higgins, J.; Thompson, S.G. Quantifying heterogeneity in a meta-analysis. Stat. Med. 2002, 21, 539-558. [CrossRef]

43. Colditz, G.A.; Burdick, E.; Mosteller, F. Heterogeneity in meta-analysis of data from epidemiologic studies: A commentary. Am. J. Epidemiol. 1995, 142, 371-382. [CrossRef]

44. Baujat, B.; Mahé, C.; Pignon, J.P.; Hill, C. A graphical method for exploring heterogeneity in meta-analyses: Application to a meta-analysis of 65 trials. Stat. Med. 2002, 21, 2641-2652. [CrossRef] [PubMed]

45. Egger, M.; Smith, G.D.; Schneider, M.; Minder, C. Bias in meta-analysis detected by a simple, graphical test. BMJ 1997, 315, 629-634. [CrossRef] [PubMed]

46. Peters, J.L.; Sutton, A.J.; Jones, D.R.; Abrams, K.R.; Rushton, L. Performance of the trim and fill method in the presence of publication bias and between-study heterogeneity. Stat. Med. 2007, 26, 4544-4562. [CrossRef] [PubMed]

47. Viechtbauer, W.; Cheung, M.W.-L. Outlier and influence diagnostics for meta-analysis. Res. Synth. Methods 2010, 1, 112-125. [CrossRef] [PubMed]

48. Viechtbauer, W.; López-López, J.A.; Sánchez-Meca, J.; Marín-Martínez, F. A comparison of procedures to test for moderators in mixed-effects meta-regression models. Psychol. Methods 2015, 20, 360-374. [CrossRef] [PubMed]

49. Thompson, S.G.; Sharp, S.J. Explaining heterogeneity in meta-analysis: A comparison of methods. Stat. Med. 1999, 18, 2693-2708. [CrossRef]

50. Wolter, N.; Carrim, M.; Cohen, C.; Tempia, S.; Walaza, S.; Sahr, P.; De Gouveia, L.; Treurnicht, F.; Hellferscee, O.; Cohen, A.L.; et al. Legionnaires'Disease in South Africa, 2012-2014. Emerg. Infect. Dis. 2016, 22, 131. [CrossRef]

51. Carugati, M.; Aliberti, S.; Reyes, L.F.; Sadud, R.F.; Irfan, M.; Prat, C.; Soni, N.J.; Faverio, P.; Gori, A.; Blasi, F.; et al. Microbiological testing of adults hospitalised with community-acquired pneumonia: An international study. ERJ Open Res. 2018, 4, 00096-02018. [CrossRef]

52. Song, J.H.; Oh, W.S.; Kang, C.I.; Chung, D.R.; Peck, K.R.; Ko, K.S.; Yeom, J.S.; Kim, C.K.; Kim, S.W.; Chang, H.H.; et al. Epidemiology and clinical outcomes of community-acquired pneumonia in adult patients in Asian countries: A prospective study by the Asian network for surveillance of resistant pathogens. Int. J. Antimicrob. Agents 2008, 31, 107-114. [CrossRef]

53. Aliberti, S.; Brambilla, A.M.; Chalmers, J.D.; Cilloniz, C.; Ramirez, J.; Bignamini, A.; Prina, E.; Polverino, E.; Tarsia, P.; Pesci, A.; et al. Phenotyping community-acquired pneumonia according to the presence of acute respiratory failure and severe sepsis. Respir. Res. 2014, 15, 27. [CrossRef]

54. Reissig, A.; Mempel, C.; Schumacher, U.; Copetti, R.; Gross, F.; Aliberti, S. Microbiological diagnosis and antibiotic therapy in patients with community-acquired pneumonia and acute COPD exacerbation in daily clinical practice: Comparison to current guidelines. Lung 2013, 191, 239-246. [CrossRef]

55. Walden, A.P.; Clarke, G.M.; McKechnie, S.; Hutton, P.; Gordon, A.C.; Rello, J.; Chiche, J.D.; Stueber, F.; Garrard, C.S.; Hinds, C.J. Patients with community acquired pneumonia admitted to European intensive care units: An epidemiological survey of the GenOSept cohort. Crit. Care 2014, 18, 1-9. [CrossRef] [PubMed]

56. Norrby, S.R. Atypical pneumonia in the Nordic countries: Aetiology and clinical results of a trial comparing fleroxacin and doxycycline. Nordic Atypical Pneumonia Study Group. J. Antimicrob. Chemother. 1997, 39, 499-508. [CrossRef] [PubMed]

57. Vergis, E.N.; Akbas, E.; Yu, V.L. Legionella as a cause of severe pneumonia. Semin. Respir. Crit. Care Med. 2000, 21, 295-304. [CrossRef] [PubMed]

58. Tkatch, L.S.; Kusne, S.; Irish, W.D.; Krystofiak, S.; Wing, E. Epidemiology of legionella pneumonia and factors associated with legionella-related mortality at a tertiary care center. Clin. Infect. Dis. 1998, 27, 1479-1486. [CrossRef]

59. Dominguez, A.; Alvarez, J.; Sabria, M.; Carmona, G.; Torner, N.; Oviedo, M.; Cayla, J.; Minguell, S.; Barrabeig, I.; Sala, M.; et al. Factors influencing the case-fatality rate of Legionnaires' disease. Int. J. Tuberc. Lung Dis. 2009, 13, 407-412.

60. Garbino, J.; Sommer, R.; Gerber, A.; Regamey, C.; Vernazza, P.; Genne, D.; Dür, P.; Rothen, M.; Unger, J.P.; Lew, D. Prospective epidemiologic survey of patients with community-acquired pneumonia requiring hospitalization in Switzerland. Int. J. Infect. Dis. 2002, 6, 288-293. [CrossRef] 
61. Guglielmo, L.; Leone, R. Aetiology and therapy of community-acquired pneumonia: A hospital study in northern Italy. Eur. J. Clin. Pharmacol. 1997, 51, 437-443. [CrossRef]

62. Fernández-Sabé, N.; Carratalà, J.; Rosón, B.; Dorca, J.; Verdaguer, R.; Manresa, F.; Gudiol, F. Community-acquired pneumonia in very elderly patients: Causative organisms, clinical characteristics, and outcomes. Medicine 2003, 82, 159-169. [CrossRef]

63. Olsen, S.J.; Thamthitiwat, S.; Chantra, S.; Chittaganpitch, M.; Fry, A.M.; Simmerman, J.M.; Baggett, H.C.; Peret, T.C.; Erdman, D.; Benson, R.; et al. Incidence of respiratory pathogens in persons hospitalized with pneumonia in two provinces in Thailand. Epidemiol. Infect. 2010, 138, 1811-1822. [CrossRef] [PubMed]

64. Shimada, T.; Noguchi, Y.; Jackson, J.L.; Miyashita, J.; Hayashino, Y.; Kamiya, T.; Yamazaki, S.; Matsumura, T.; Fukuhara, S. Systematic review and metaanalysis: Urinary antigen tests for Legionellosis. Chest 2009, 136, 1576-1585. [CrossRef] [PubMed]

65. Metlay, J.P.; Waterer, G.W.; Long, A.C.; Anzueto, A.; Brozek, J.; Crothers, K.; Cooley, L.A.; Dean, N.C.; Fine, M.J.; Flanders, S.A.; et al. Diagnosis and treatment of adults with community-acquired pneumonia. An official clinical practice guideline of the American Thoracic Society and Infectious Diseases Society of America. Am. J. Respir. Crit. Care. Med. 2019, 200, e45-e67. [CrossRef]

66. Migotto, T.R.C.; Lora, S.G.; Gaia, V.; Pagnamenta, A. ARDS with septic shock due to Legionella longbeachae pneumonia in a patient with polymyalgia rheumatica. Heart Lung Vessel. 2014, 6, 114.

67. Ewig, S. Community-acquired pneumonia: Definition, epidemiology, and outcome. Semin. Respir. Infect. 1999, 14, 94-102.

68. Mackenzie, G. The definition and classification of pneumonia. Pneumonia 2016, 8, 1-5. [CrossRef] [PubMed]

69. Wootton, D.; Feldman, C. The diagnosis of pneumonia requires a chest radiograph (X-ray)—yes, no or sometimes? Pneumonia 2014, 5, 1-7. [CrossRef] [PubMed]

70. Park, D.R.; Sherbin, V.L.; Goodman, M.S.; Pacifico, A.D.; Rubenfeld, G.D.; Polissar, N.L.; Harborview CAP Study Group. The etiology of community-acquired pneumonia at an urban public hospital: Influence of human immunodeficiency virus infection and initial severity of illness. J. Infect. Dis. 2001, 18, 268-277. [CrossRef]

71. Bao, Z.; Yuan, X.; Wang, L.; Sun, Y.; Dong, X. The incidence and etiology of community-acquired pneumonia in fever outpatients. Exp. Biol. Med. 2012, 237, 1256-1261. [CrossRef] [PubMed]

72. Lagerstrom, F.; Bader, M.; Foldevi, M.; Fredlund, H.; Nordin-Olsson, I.; Holmberg, H. Microbiological etiology in clinically diagnosed community-acquired pneumonia in primary care in Orebro, Sweden. Clin. Microbiol. Infect. 2003, 9, 645-652. [CrossRef]

73. Lieberman, D.; Shvartzman, P.; Ben-Yaakov, M.; Lazarovich, Z.; Hoffman, S.; Mosckovitz, R.; Ohana, B.; Leinonen, M.; Luffy, D.; Boldur, I. Etiology of respiratory tract infection in adults in a general practice setting. Eur. J. Clin. Microbiol. Infect. Dis. 1998, 17, 685-689. [CrossRef] [PubMed]

74. Rocha, R.T.; Vital, A.C.; Silva, C.; Pereira, C.A.; Nakatani, J. Community-acquired pneumonia in outpatients: Epidemiological, clinical and radiographic features between atypical and non-atypical pneumonia. J. Pneumol. 2000, 26, 5-14. [CrossRef]

75. Marrie, T.J.; De Carolis, E.; Yu, V.L.; Stout, J.E. Legionnaires' Disease-Results of a Multicenter Canadian Study. Can. J. Infect. Dis. Med. Microbiol. 2003, 14, 154-158. [CrossRef]

76. Pierre, D.M.; Baron, J.; Victor, L.Y.; Stout, J.E. Diagnostic testing for Legionnaires' disease. Ann. Clin. Microbiol. Antimicrob. 2017, 16, 59. [CrossRef] [PubMed]

77. Bochud, P.Y.; Moser, F.; Erard, P.; Verdon, F.; Studer, J.P.; Villard, G.; Cosendai, A.; Cotting, M.; Heim, F.; Tissor, J.; et al. Community-acquired pneumonia. A prospective patient study. Medicine 2001, 80, 75-87. [CrossRef] [PubMed]

78. Simmering, J.E.; Polgreen, L.A.; Hornick, D.B.; Sewell, D.K. Weather-dependent risk for Legionnaires' disease, United States. Emerg. Infect. Dis. 2017, 23, 1843-1851. [CrossRef] 